Available online at GSC Online Press Directory

GSC Biological and Pharmaceutical Sciences

e-ISSN: 2581-3250, CODEN (USA): GBPSC2

(RESEARCH ARTICLE)

\title{
Spectroscopic analysis and anti-inflammatory effects of Milicia excelsa (Moraceae) leaf and fractions
}

\author{
Akinpelu Lateef Abiola 1, 2,* , Olawuni Idowu Julius ${ }^{3}$, Ogundepo Gbenga Emmanuel ${ }^{3}$, Adegoke Adesoji Mutiu \\ ${ }^{4}$, Olayiwola Gbola ${ }^{5}$ and Idowu Thomas Oyedode ${ }^{6}$ \\ ${ }^{1}$ Department of Pharmacology and Toxicology, College of Pharmacy, Igbinedion University, Okada, Edo State, Nigeria. \\ 2 Department of Pharmacology, Faculty of Pharmacy, Obafemi Awolowo University Ile-Ife, Osun State, Nigeria. \\ ${ }^{3}$ Department of Biochemistry, Faculty of Science, Obafemi Awolowo University Ile-Ife, Osun State, Nigeria. \\ ${ }^{4}$ Central Science Laboratory, Obafemi Awolowo University Ile-Ife, Osun State, Nigeria. \\ ${ }^{5}$ Department of Clinical Pharmacy, Faculty of Pharmacy, Obafemi Awolowo University Ile-Ife, Osun State, Nigeria. \\ ${ }^{6}$ Department of Pharmaceutical Chemistry, Faculty of Pharmacy, Obafemi Awolowo University Ile-Ife, Osun State, \\ Nigeria.
}

Publication history: Received on 15 February 2019; revised on 07 March 2019; accepted on 11 March 2019

Article DOI: https://doi.org/10.30574/gscbps.2019.6.3.0035

\begin{abstract}
This study evaluated the spectroscopic and anti-inflammatory properties of the ethanol leaf extract of Milicia excelsa and fractions. The anti-inflammatory activities of the extract and various organic fractions were investigated using bovine erythrocyte membrane stabilizing assay. Ultraviolet-visible (UV-VIS) and Fourier transform-infrared (FT-IR) methods were used to detect the characteristic peak values and their functional groups. The results showed that the crude extract and ethyl acetate fraction showed minimum percentage inhibitions of $0.88 \pm 0.30$ and $72.05 \pm 0.45 \%$ and maximum percentage inhibitions of $81.66 \pm 0.23 \%$ and $99.07 \pm 0.30 \%$ respectively compared to the standard antiinflammatory drug (Indomethacin) which exhibited minimum and maximum percentage inhibitions of $52.64 \pm 0.83$ and $75.51 \pm 1.52 \%$ respectively. The UV-VIS profile showed the peaks ranging from 270 to $670 \mathrm{~nm}$ with the absorption values from 0.040 - 0.720 which could confirm the presence of aromatic compounds, alkaloids, flavonoids, unsaturated conjugated compounds in the plant. In addition, the FT-IR revealed diagnostic peaks around 3570-3200, 3000-2800, 2865-2845, 2850-2815, 2820-2780, 2070-2000, 1630-1750, 1640-1450, 1340-1250, 1200-1000, 800-700 nm-1 which could confirm the presence of phenols/alcohol/carboxylic acids, alkanes, diazocompounds, aldehyde /ketone/ amide/ester, alkenes/aromatic compounds, ethers/phosphate compounds, aliphatic/chloro compounds respectively in Milicia excelsa. This study therefore demonstrated that ethyl acetate fraction with the highest percentage inhibition contained bioactive principles that protected the erythrocyte membranes effectively from lyses and also exhibited both monophasic and biphasic modes. The study also produced the UV-VIS and FT-IR spectrum profile for Milicia excelsa leaf which could be used to identify the plant biomarkers and chemical markers.
\end{abstract}

Keywords: Milicia excelsa; Anti-inflammatory; Membrane stabilizing assay; Plant biomarkers

\section{Introduction}

Inflammation is a pathophysiological response of the body to injury, infection or destruction characterized by heat, redness, pain, swelling and disturbed functions [1]. It is a primary physiological defensive mechanism that assists the body in protecting itself against noxious stimuli, toxic chemicals, infection, burn or allergens [2]. Although inflammation is a bodily defensive mechanism, attendant complex events and mediators that are involved in the inflammatory reaction can induce, maintain or worsen many diseases [3]. The nonsteroidal anti-inflammatory drugs are the most

\footnotetext{
${ }^{*}$ Corresponding author

E-mail address: akinpelu_abiola01@yahoo.com
}

Copyright (C) 2019 Author(s) retain the copyright of this article. This article is published under the terms of the Creative Commons Attribution Liscense 4.0. 
commonly used anti-inflammatory drugs but with attendant side effects especially gastric irritation leading to gastric ulcers [4] [5]. Therefore, the development of potent anti-inflammatory drugs with fewer side effects is a step in the right direction.

The detection and identification of functional groups in phytochemicals present in medicinal plants by the use of UVVisible (UV-Vis) and Fourier transform-infrared (FT-IR) spectroscopic techniques guarantee immense value, because of their simplicity and cost-effectiveness [6]. FT-IR is an established time-saving method known for its unique "fingerprint" of any compound and for the detection and identification of various functional groups in plant extracts [6] [7] [8]. However, the study of the phytochemicals of Milicia excelsa (M. excelsa) leaf extract and fractions and their antiinflammatory effects are rare in the literature. Therefore, the main objective was to carry out the profiling of the functional groups of the phytochemicals present in M. excelsa leaf extract and fractions using UV-Vis and FT-IR spectroscopic techniques and to evaluate their anti-inflammatory properties.

Milicia excelsa (welw.) C.C. Berg popularly called African teak or Iroko belongs to the family Moraceae and it is a large deciduous tree growing up to 30 to $50 \mathrm{~m}$ high and naturally occurring in humid forests of West Africa [9]. Its various parts such as the latex, leaf, stem bark, root, fruit and ashes are used in African traditional medicine to prepare traditional medicines for the treatment of: malaria [10], mental illnesses [11] [12] [13], sexual dysfunction [14], rheumatism [15], stomach problems, hypertension, tumours and obstructions of the throat [12]. Biologically, the antibacterial [16], anti-amoebic [17], wound healing [18] and in-vivo anti-inflammatory properties of the stem bark extract have been demonstrated [19]. The present study reported the anti-inflammatory activity of M. excelsa leaf extract and fractions, using bovine red blood stabilization bio-assay; as well as the profile of the functional moieties of phytochemicals present that could be responsible for the anti-inflammatory effects using UV-Vis and FT-IR spectroscopic analysis.

\section{Material and methods}

\subsection{Plant identification and authentication}

Milicia excelsa leaves were collected within the campus of the Obafemi Awolowo University (OAU) Ile Ife Nigeria. It was identified and authenticated by Mr. G. A. Ademoriyo of the Herbarium Unit, Department of Botany, Faculty of Sciences, $\mathrm{OAU}$, Ile-Ife and herbarium number Ife-17482 was obtained.

\subsection{Preparation of plant materials}

The leaves of M. excelsa were air dried at room temperature. The dried leaves were pulverized and $1.0 \mathrm{~kg}$ of the powder was extracted with 3 liters of $70 \%$ ethanol for $72 \mathrm{~h}$. The marc was re-extracted once and the combined extract was concentrated in vacuo at a temperature of $40^{\circ} \mathrm{C}$ to yield $70 \mathrm{~g} \mathrm{(7.0 \% )} \mathrm{crude} \mathrm{extract} \mathrm{and} \mathrm{coded} \mathrm{(EME).} \mathrm{Sixty} \mathrm{grams} \mathrm{of} \mathrm{the}$ crude extract was successively partitioned into $n$-hexane, ethyl acetate, $n$-butanol and aqueous fractions. The fractions were again concentrated in vacuo to give n-hexane, ethyl-acetate, butanol, and aqueous fractions [20].

\subsection{Spectroscopic analysis}

The UV-VIS spectrum of the ethanol leaf extract of M. excelsa and the various fractions were obtained with a UV spectrophotometer in the wavelength range of $190-900 \mathrm{~nm}$. The FT-IR spectrum of each of the sample was mixed with spectra-grade potassium bromide $(\mathrm{KBr})$ in the ratio of 1:100 and pressed to a pellet. The pressed pellet was immediately inserted into the sample holder of Perkin Elmer Spectrophotometer and was operated in the range $4000-400 \mathrm{~cm}^{-1}$. Hence, the different functional groups present in each sample were detected from the spectral data obtained.

\subsection{Preparation of drugs}

The reference drug (Indomethacin, $1.0 \mathrm{mg} / \mathrm{ml}$ ) and various extracts/fractions were prepared in isosaline $(0.85 \% \mathrm{w} / \mathrm{v}$ $\mathrm{NaCl}$ ) to give final concentrations of $0.1-0.5 \mathrm{mg} / \mathrm{ml}$.

\subsection{The bovine red blood cell preparation}

The bovine red blood cell was prepared as previously described [21].

\subsection{The membrane stabilizing activity assay}

The assay for the membrane stabilizing activity of the ethanol leaf extract and fractions was carried out as previously described [21-23]. 


\section{Results}

\subsection{Membrane stabilizing assay}

Figures $1 \mathrm{~A}$ - E showed the percentage inhibitions of hemolysis of the red blood cell membrane by the ethanol leaf extract and various fractions of $M$. excelsa on bovine red blood cell exposed to both heat and hypotonic induced lyses. The ethanol extract showed minimum and maximum percentage inhibitions of $0.88 \pm 0.30$ and $81.66 \pm 0.23 \%$, the mode of responses of the erythrocyte were both monophasic and biphasic (Fig $1 \mathrm{~A}$ ). The hexane fraction exhibited minimum and maximum percentage inhibitions of $20.10 \pm 1.02$ and $52.31 \pm 0.27 \%$, the mode of response of the erythrocyte was both monophasic and biphasic (Fig $1 \mathrm{~B}$ ). EAF exhibited minimum and maximum percentage inhibitions of $72.04 \pm 0.45 \%$ and $99.07 \pm 0.30 \%$, the mode of response of the erythrocyte was both monophasic and biphasic (Fig $1 \mathrm{C}$ ). BF showed minimum and maximum percentage inhibition of $6.15 \pm 0.74 \%$ and $25.16 \pm 1.63 \%$, the mode of response of the erythrocyte was both monophasic and biphasic (Fig $1 \mathrm{D}$ ) while the AF exhibited minimum and maximum percentage inhibition of $1.64 \pm 0.31 \%$ and $50.15 \pm 1.20 \%$, the mode of response of the erythrocyte was both monophasic and biphasic (Fig $1 \mathrm{E}$ ). The standard anti-inflammatory drug (Indomethacin) exhibited minimum and maximum percentage inhibition of $52.65 \pm 0.83$ and $75.55 \pm 1.52 \%$, the mode of response of the erythrocyte was both monophasic and biphasic.
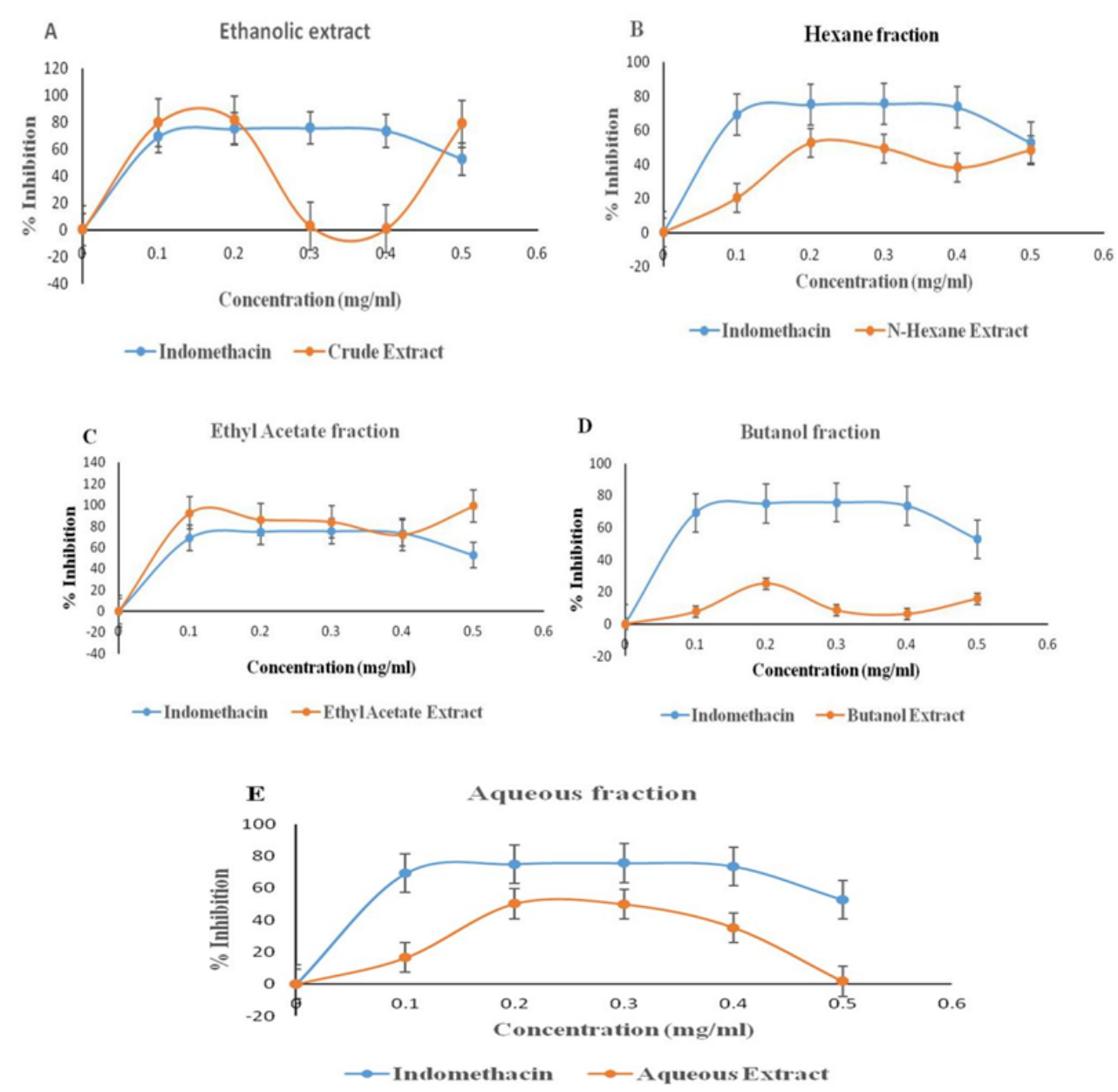

Figure 1 A - E Membrane stabilizing properties of ethanol extract (A); hexane fraction (B); ethyl acetate fraction (C); butanol fraction (D) and aqueous fraction (E) of M. excelsa; on bovine red blood cells subjected to both heat and hypotonic induced lyses. Each value represents the mean of four readings \pm SEM.

\subsection{UV-VIS spectral data interpretation}

The extract and all the fractions of M. excelsa (Table 1) peak at the range of 234- $676 \mathrm{~nm}$ which revealed the presence of phenolics and alkaloids. The absorption peaks in the region of $400-420 \mathrm{~nm}$ found in the ethanol extract, HF and EAF revealed the presence of quinones and absorption in the UV region of 600-660 $\mathrm{nm}$ found in ethanol extract and revealed the presence of chlorophyll. The absorption peaks in the UV region of 220-280 $\mathrm{nm}$ found in ethanol extract and all the 
fractions and in the range of 330- $420 \mathrm{~nm}$ found in ethanol extract; HF and EAF correspond to phenolic acids and derivatives.

Table 1 UV-VIS peak values of crude extract and various organic fractions of Milicia excelsa leaf

\begin{tabular}{lll}
\hline S/N. & Wavelength (nm) & Absorption \\
\hline Ethanol extract & \\
$1 . \quad 270$ (Flavonoids) - (band I) & 1.450 \\
$2 . \quad 305$ (Flavonoids) - (band II) & 0.880 \\
$3 . \quad 410$ (terpenoids) & 0.615 \\
$4 . \quad 670$ (chlorophyll) & 0.230 \\
\hline Hexane fraction & 0.250 \\
$1 . \quad 280$ (Flavonoids) - (band I) & 0.155 \\
$2 . \quad 350$ & 0.105 \\
$3 . \quad 410$ (terpenoids) & 0.065 \\
$4 . \quad 670$ (chlorophyll) & 0.450 \\
\hline Ethyl acetate fraction & 0.105 \\
$1 . \quad 310$ (Flavonoids) - (band II) & 0.040 \\
$2 . \quad 350$ (Flavonoids) - (band II) \\
$3 . \quad 405$ (terpenoids) \\
\hline Butanol fraction \\
$1 . \quad 280$ (Flavonoids) - (band I) \\
$2 . \quad 330$ (Flavonoids) - (band II) \\
$3 . \quad 420$ (terpenoids) \\
Aqueous fraction \\
$1 . \quad 280$ (Flavonoids) - (band I) \\
$2 . \quad 350$ (Flavonoids) - (band II) \\
$3 . \quad 405$ (terpenoids) \\
\hline
\end{tabular}

\subsection{FT-IR spectral data}

\subsubsection{The ethanol extract}

Ethanol (EME) leaf extract exhibited a characteristic band at 3334.1, 2946.5, 2834.5, 1654.9, 1449.8, 1410.8, 1112.6 and $1017 \mathrm{~cm}^{-1}$ indicating the presence of $\mathrm{OH}, \mathrm{C}-\mathrm{H}$ stretch aliphatic, $\mathrm{C}-\mathrm{H}, \mathrm{C}=\mathrm{O}, \mathrm{C}=\mathrm{C}-\mathrm{C}$ aromatic ring stretch, $\mathrm{OH}$ alcoholic, $\mathrm{P}=\mathrm{O}$ stretch and C-O-C stretch groups respectively (Table 2).

\subsubsection{Hexane fraction $(H F)$}

The hexane fraction exhibited a characteristic band at 3354.6, 2922.2, 2853.3, 2023.9, 1707.1, 1459.3, 1377.3,1313.9, $1243.1,1161.1,1034.3,780.9 \mathrm{~cm}^{-1}$ indicating the presence of $\mathrm{OH}, \mathrm{C}-\mathrm{H}$ stretch aliphatic, $\mathrm{CH}\left(\mathrm{CH}_{2}\right), \mathrm{CNN}$ stretch, $\mathrm{C}=\mathrm{O}, \mathrm{C}=\mathrm{C}-$ $\mathrm{C}$ aromatic ring stretch, $\mathrm{OH}$ alcoholic, $\mathrm{OH}$ alcoholic , $\mathrm{C}-\mathrm{N}, \mathrm{C}-\mathrm{O}, \mathrm{C}-\mathrm{O}-\mathrm{C}$ and $\mathrm{C}-\mathrm{Cl}$ stretch groups respectively (Table 2).

\subsubsection{Ethyl acetate fraction $(E A F)$}

Ethyl acetate fraction (EAF) leaf extract exhibited a characteristic band at 3324.8, 2942.7, 2830.0, 2038.0, 1656.8, 1448.1, 1420.1 and $1019.4 \mathrm{~cm}^{-1}$ indicating the presence of $\mathrm{OH}, \mathrm{C}-\mathrm{H}$ stretch aliphatic, $\mathrm{C}-\mathrm{H}, \mathrm{CNN}, \mathrm{C}=\mathrm{O}, \mathrm{C}=\mathrm{C}-\mathrm{C}, \mathrm{OH}$ alcoholic and phosphate ion groups respectively (Table 2).

\subsubsection{Butanol fraction $(B F)$}

Butanol fraction (BF) leaf extract exhibited a characteristic band at 3322.9, 2944.8, 2832.8, 1654.9, 1448.1, 1410.8, 1112.6 and $1019.4 \mathrm{~cm}^{-1}$ indicating the presence of $\mathrm{OH}, \mathrm{C}-\mathrm{H}$ stretch aliphatic, $\mathrm{C}-\mathrm{H}, \mathrm{C}=\mathrm{O}, \mathrm{C}=\mathrm{C}-\mathrm{C}$ aromatic ring stretch, $\mathrm{OH}$ alcoholic, $\mathrm{P}=\mathrm{O}$ stretch and phosphate ion groups respectively (Table 2).

\subsubsection{Aqueous fraction (AF)}

Aqueous fraction (AF) leaf extract exhibited a characteristic band at 3321.1, 2944.6, 2832.8, 1662.4, 1448.2, 1412.7, 1112.6 and $1019.4 \mathrm{~cm}^{-1}$ indicating the presence of $\mathrm{OH}, \mathrm{C}-\mathrm{H}$ stretch aliphatic, $\mathrm{C}-\mathrm{H}, \mathrm{C}=\mathrm{O}, \mathrm{C}=\mathrm{C}-\mathrm{C}$ aromatic ring stretch, $\mathrm{OH}$ alcoholic, $\mathrm{P}=\mathrm{O}$ stretch and phosphate ion groups respectively (Table 2 ). 
Table 2 FTIR profile of Milicia excelsa leaf extract and various organic fractions

\begin{tabular}{|c|c|c|c|c|}
\hline $\begin{array}{l}\text { Extract/f } \\
\text { raction }\end{array}$ & $\begin{array}{l}\text { Frequency (Wave } \\
\text { number } \mathrm{cm}^{-1} \text { ) } \\
\text { Test sample }\end{array}$ & $\begin{array}{l}\text { Frequency (Wave } \\
\text { number } \mathrm{cm}^{-1} \text { ) } \\
\text { Reference article }\end{array}$ & Bond Assignments & $\begin{array}{l}\text { Functional groups } \\
\text { present }\end{array}$ \\
\hline \multicolumn{5}{|c|}{ Ethanol extract } \\
\hline 1 & 3334.1 & $3570-3200$ & $\mathrm{O}-\mathrm{H}$ stretch, $\mathrm{H}$ - bonded & $\begin{array}{l}\text { phenols, alcohol, polyhydroxy } \\
\text { compounds }\end{array}$ \\
\hline 2 & 2946.5 & $3000-2800$ & H-C-H stretch & alkanes \\
\hline 3. & 2834.5 & $2850-2815$ & C-H stretch & methoxy methyl ether \\
\hline 4. & 1654.9 & $1690-1640$ & $\mathrm{C}=\mathrm{O}$ stretch & amide \\
\hline 5. & 1449.8 & $1510-1450$ & $\mathrm{C}=\mathrm{C}-\mathrm{C}$ aromatic stretch & aromatic compounds \\
\hline 6 & 1410.8 & $1410-1310$ & $\mathrm{O}-\mathrm{H}$ bend & phenols or tertiary alcohol \\
\hline 7. & 1112.6 & $1200-1100$ & $\mathrm{P}=0$ stretch & phosphate compounds \\
\hline 8. & 1017.6 & $1050-1000$ & $\mathrm{C}-\mathrm{O}-\mathrm{C}$ stretch & ether \\
\hline \multicolumn{5}{|c|}{ Hexane fraction } \\
\hline 1. & 3354.6 & $3570-3200$ & $\mathrm{O}-\mathrm{H}$ stretch, $\mathrm{H}$ - bonded & $\begin{array}{l}\text { phenols, alcohol, polyhydroxy } \\
\text { compounds }\end{array}$ \\
\hline 2. & 2922.2 & $3000-2800$ & H-C-H stretch & alkanes \\
\hline 3. & 2853.3 & $2865-2845$ & $\mathrm{CH}\left(\mathrm{CH}_{2}\right)$ & lipids, protein \\
\hline 4. & 2023.9 & $2100-2000$ & -CNN stretch & diazocompounds \\
\hline 5. & 1707.1 & $1750-1705$ & $\mathrm{C}=\mathrm{O}$ stretch & ketone \\
\hline 6. & 1459.3 & $1510-1450$ & $\mathrm{C}=\mathrm{C}-\mathrm{C}$ aromatic stretch & aromatic compounds \\
\hline 7 & 1377.3 & $1410-1310$ & $\mathrm{O}-\mathrm{H}$ bend & phenols or tertiary alcohol \\
\hline 8. & 1313.9 & $1410-1310$ & $\mathrm{O}-\mathrm{H}$ bend & phenols or tertiary alcohol \\
\hline 9. & 1243.1 & $1340-1250$ & C-N stretch & aromatic primary amine \\
\hline 10. & 1161.1 & $1200-1125$ & $\mathrm{C}-\mathrm{O}$ stretch & tertiary alcohol \\
\hline 11. & 1034.3 & $1075-1020$ & $\mathrm{C}-\mathrm{O}-\mathrm{C}$ & ethers \\
\hline 12. & 780.9 & $800-700$ & $\mathrm{C}-\mathrm{Cl}$ stretch & aliphatic chloro compounds \\
\hline \multicolumn{5}{|c|}{ Ethyl acetate fraction } \\
\hline 1. & 3324.8 & $3570-3200$ & $\mathrm{O}$-H stretch, $\mathrm{H}$ - bonded & $\begin{array}{l}\text { phenols, alcohol, polyhydroxy } \\
\text { compounds }\end{array}$ \\
\hline 2. & 2942.7 & $3000-2800$ & H-C-H stretch & alkanes \\
\hline 3. & 2830.9 & $2850-2815$ & C-H stretch & methoxy methyl ether \\
\hline 4. & 2038.9 & $2070-2030$ & -CN2 stretch & diazomethylene compounds \\
\hline 5. & 1656.8 & $1690-1640$ & $\mathrm{C}=\mathrm{O}$ stretch & amide \\
\hline 6. & 1448.1 & $1510-1450$ & $\mathrm{C}=\mathrm{C}-\mathrm{C}$ aromatic & aromatic compounds \\
\hline 7. & 1420.1 & $1420-1330$ & $\mathrm{O}-\mathrm{H}$ bending & alcohol \\
\hline 8. & 1114.5 & & & \\
\hline 9. & 1021.3 & $1054-1019$ & phosphate ion & phosphate compounds \\
\hline \multicolumn{5}{|c|}{ Butanol fraction } \\
\hline 1. & 3322.9 & $3570-3200$ & $\begin{array}{l}\mathrm{O}-\mathrm{H} \text { stretch group, } \mathrm{H}- \\
\text { bonded }\end{array}$ & $\begin{array}{l}\text { phenols, alcohol polyhydroxy } \\
\text { compounds }\end{array}$ \\
\hline 2. & 2944.8 & $3000-2800$ & H-C-H stretch & alkanes \\
\hline 3. & 2832.8 & $2850-2815$ & $\mathrm{C}-\mathrm{H}$ stretch & methoxy methyl ether \\
\hline 4. & 1654.9 & $1690-1640$ & $\mathrm{C}=\mathrm{O}$ stretch & amide \\
\hline 5. & 1448.1 & $1510-1450$ & $\mathrm{C}=\mathrm{C}-\mathrm{C}$ aromatic stretch & aromatic compounds \\
\hline 6. & 1410.8 & $1410-1310$ & $\mathrm{O}-\mathrm{H}$ bend & phenols or tertiary alcohol \\
\hline 7. & 1112.6 & $1200-1100$ & $\mathrm{P}=0$ stretch & phosphate compounds \\
\hline 8. & 1019.4 & $1054-1019$ & phosphate ion & phosphate compounds \\
\hline \multicolumn{5}{|c|}{ Aqueous fraction } \\
\hline 1. & 3321.1 & $3570-3200$ & $\mathrm{O}$-H stretc, $\mathrm{H}$ - bonded & $\begin{array}{l}\text { phenols, alcohol, polyhydroxy } \\
\text { compounds }\end{array}$ \\
\hline 2. & 2944.6 & $3000-2800$ & H-C-H stretch & alkanes \\
\hline 3. & 2832.8 & $2850-2815$ & $\mathrm{C}-\mathrm{H}$ stretch & methoxy methyl ether \\
\hline 4. & 1662.4 & $1670-1600$ & $\mathrm{C}=0$ stretch & amides \\
\hline 5. & 1448.2 & $1510-1450$ & $\mathrm{C}=\mathrm{C}-\mathrm{C}$ aromatic stretch & aromatic compounds \\
\hline 6. & 1412.7 & $1410-1310$ & O-H bend & phenols or tertiary alcohol \\
\hline 7. & 1112.6 & $1200-1100$ & $\mathrm{P}=0$ stretch & phosphate compounds \\
\hline 8. & 1019.4 & $1054-1019$ & phosphate ion & phosphate compounds \\
\hline
\end{tabular}



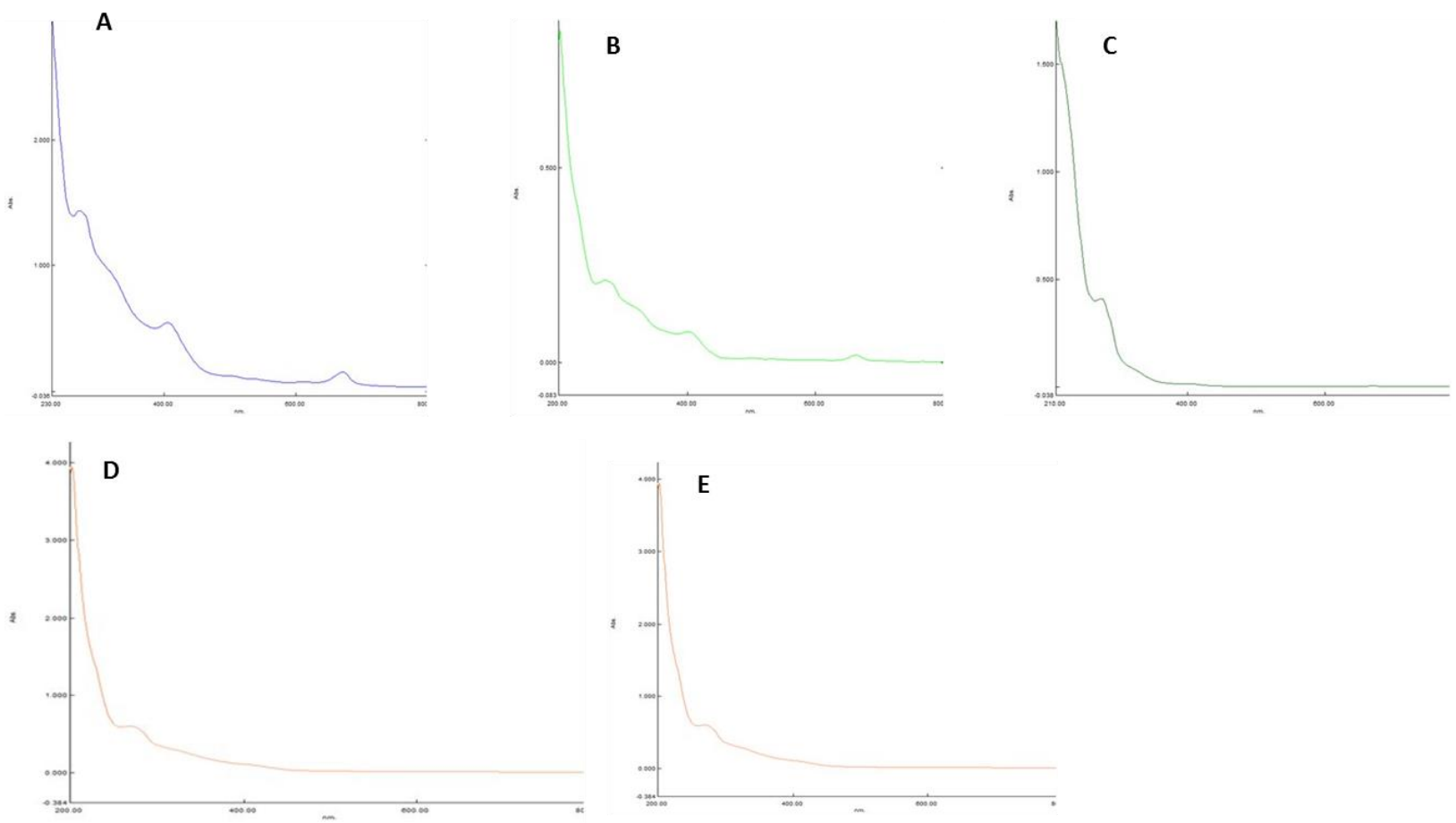

Figure 2 A - E UV-VIS spectrum profile of ethanol leaf extract and fractions of Milicia excels. A - Ethanol leaf extract, B - n- hexane fraction, C - Ethyl acetate fraction, D - n-butanol fraction, E - Aqueous fraction.
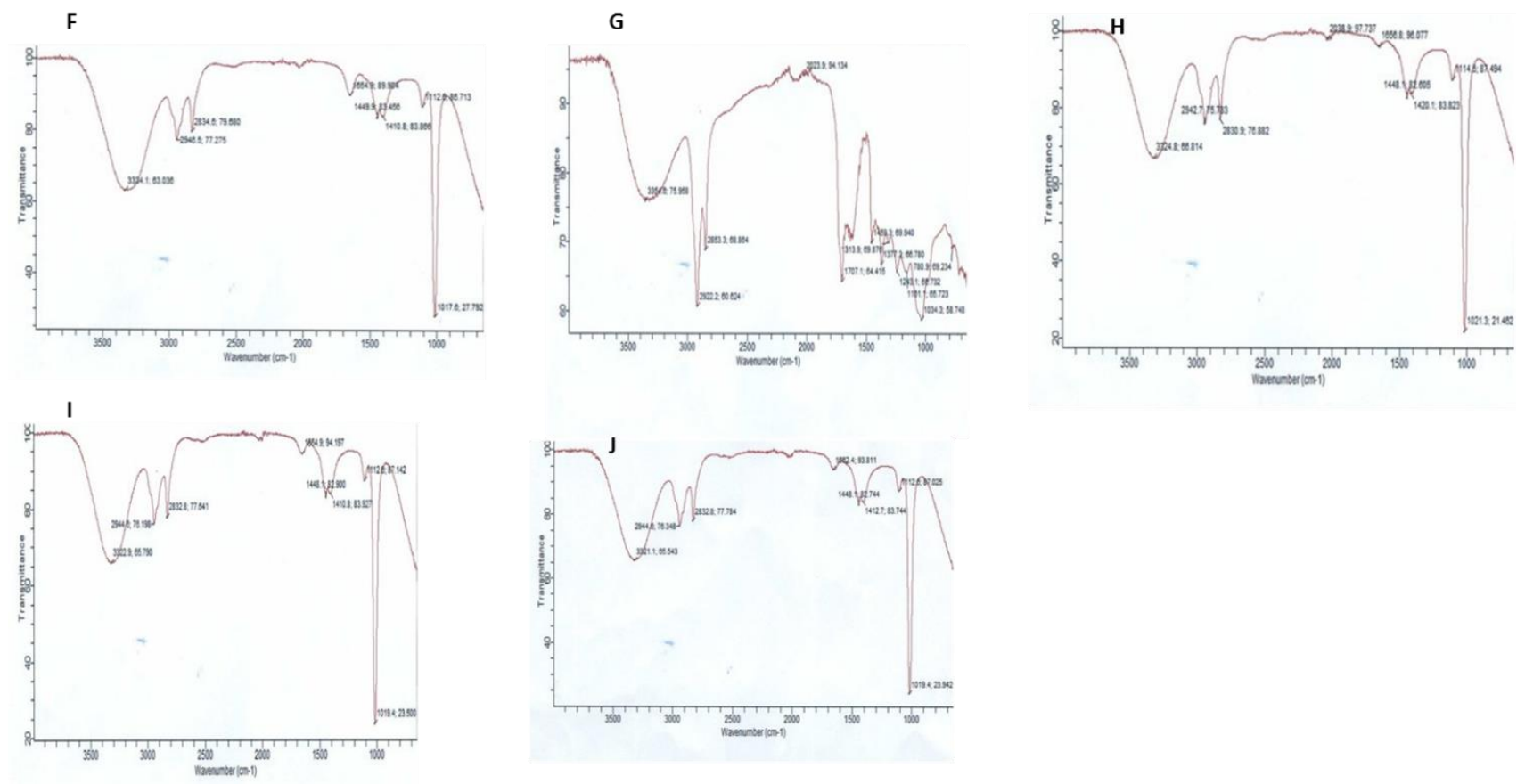

Figure 2 F - J FTIR spectrum profile of ethanol leaf extract and fractions of Milicia excels. F - Ethanol leaf extract, G - nhexane fraction, $\mathrm{H}$ - Ethyl acetate fraction, I - n-butanol fraction, J - Aqueous fraction.

\section{Discussion}

Plants derived drugs have been demonstrated to contain principles that possess the ability to facilitate the stability of biological membranes when exposed to induced lyses [21] [22]. The result of this investigation presented the membrane stabilizing activities of M. excelsa extract and fractions (Figures 1A - E). The extract and fractions have varying degrees of inhibition of the hemolysis of bovine erythrocyte cells. Ethanol extract (Figure 1A) and EAF (Figure 1C) showed the 
highest percentage inhibition of $81.66 \pm 0.23 \%$ and $99.07 \pm 0.30 \%$ respectively, hence, they are considered highly potent against heat and hypotonic induced lyses. Both ethanol extract and the ethyl acetate fraction therefore, contained principles that protected the erythrocytes membranes effectively. Moreover, ethyl acetate fraction offered the highest protection against induced lyses. The activities of the ethanol extract and ethyl acetate fraction were comparable to that of a standard anti-inflammatory drug (Indomethacin).

An earlier report has suggested that the mechanism of action of the membrane stabilizing effect of the extracts of Lantana camara and its fractions as well as the reference anti-inflammatory agent could be connected with binding to the erythrocyte membranes with subsequent alteration of the surface charges of the cells [23]. This binding could have prevented the physical interaction with aggregating agents or promote dispersal by mutual repulsion of like charges which are involved in the red blood cells hemolysis [23]. Therefore, the anti-inflammatory effect of Milicia excelsa ethanol extract and fractions could as well be due to this mechanism.

Recent research efforts toward drug discovery from medicinal plants are a multifaceted approach that combines botanical, phytochemical, biological and molecular techniques [24]. Plant based drugs have been reported to have an array of secondary metabolites like alkaloids, flavonoids, phenols, peptides, steroids, tannins and other phytocompounds [25]. Bioactive principles in medicinal plants are responsible for their therapeutic activities such as anti-carcinogenic, anticholinergic, anti-diabetic, anti-inflammatory, anti-leprosy activities, anti-malarial, anti-microbial, anti-oxidant among others [26].

The UV-VIS profile of the crude plant extract and fractions showed the peaks ranging from 270 to $670 \mathrm{~nm}$ with the absorption values from $0.040-0.720$ (Table 1). The two absorption maxima in the ranges $230-285 \mathrm{~nm}$ (band I) and $300-350 \mathrm{~nm}$ (band II) are diagnostically characteristic of the presence of flavonoids while maximum absorptions in the range from 260 to $300 \mathrm{~nm}$ are characteristic of alkaloids occurrence [27]. Furthermore, the peaks ranging from 400$710 \mathrm{~nm}$ is characteristic of the presence of terpenoids and unsaturated conjugated compounds. Hence the UV-VIS profile of M. excelsa revealed the presence of flavonoids, alkaloids, terpenoids, and unsaturated conjugated compound.

FT-IR spectroscopic analysis of the crude and various organic fractions (Table 2) revealed that, the peak at 3321-3354.6 $\mathrm{cm}^{-1}$ assigned as hydrogen bonded $\mathrm{O}-\mathrm{H}$ or $\mathrm{N}-\mathrm{H}$ stretching is attributable to the existence of phenols, alcohols, and polyhydroxyl compounds or amines. However, it is unambiguously clear that amine is not present as revealed by the absence of very sharp peak either doublet or singlet which represent primary and secondary amine respectively in this region. The peaks at 2922.2-2946.5 cm-1 assigned as sp3 H-C-H stretch are attributable to alkanes; $2853.3 \mathrm{~cm}^{-1}$ assigned as $\mathrm{CH}\left(\mathrm{CH}_{2}\right)$ stretch are due to alkane, lipids, and protein; $2830.9-2834.6 \mathrm{~cm}^{-1}$, designated as $\mathrm{OCH}_{3}, \mathrm{C}-\mathrm{H}$ stretch are due to the manifestation of methoxy/methyl ether in the plant chemical constituent; The vibrations between 2023.9-2038.9 $\mathrm{cm}^{-1}$ ascribed as $-\mathrm{CN} \equiv \mathrm{N}$ stretch are attributable to diazomethylene compounds or diazo compounds; $1707.1 \mathrm{~cm}^{-1}$ allotted as $\mathrm{C}=0$ stretch are attributable to the presence of either carbonyl of an aldehyde or ketone while or amide $1654.9-1662.4 \mathrm{~cm}^{-1}$ assigned to $\mathrm{C}=0$ stretch are attributable to amide. Consequently, the conspicuously missing frequencies at $1735-1760 \mathrm{~cm}^{-1}$ from the IR spectrum unequivocally revealed the absence of an ester carbonyl in the chemical constituents of the plant. Furthermore, the peaks at $1449.8 \mathrm{~cm}^{-1}$ assigned to $\mathrm{C}=\mathrm{C}-\mathrm{C}$ aromatic stretch is attributed to the occurrence of aromatic compounds in the plant chemical constituents. In addition, the frequency peaks at $1410.8 \mathrm{~cm}^{-1}$ due to $0-\mathrm{H}$ bend is characteristics of either alcoholic or phenols or tertiary alcohols while the peaks at $1021.3-1161 \mathrm{~cm}^{-1}$ due to $\mathrm{C}-\mathrm{O}-\mathrm{C}$ or $\mathrm{P}=0$ stretch are characteristics of either ethers or phosphate compounds; $1017.6 \mathrm{~cm}^{-1}$ assigned to $\mathrm{C}-\mathrm{O}-\mathrm{C}$ stretch are attributable to occurrence of either ether or carboxylic acid while the peak at $780.9 \mathrm{~cm}^{-1}$ designated as $\mathrm{C}-\mathrm{Cl}$ stretch are attributable to the incidence of aliphatic chloro compounds. It is therefore not surprising that M. excelsa is employed in the treatment of inflammation, rheumatism, hypertension, tumors, wound healing as previously highlighted; since phenolic and polyhydroxyl phytochemicals and alkaloids or nitrogen present in $M$. excelsa as revealed by the FT-IR have been reported in various studies to exhibit anti-inflammatory, antihypertensive, antimicrobial, antiviral, antimutagenic, and antitumor, effects among others [28-37].

The result of this finding further revealed that only the ethyl acetate fraction of $M$. excelsa leaf extract demonstrated excellent anti-inflammatory potential against bovine erythrocyte lyses. It is worth mentioning that it is the only fraction that gave absorption band of $2038 \mathrm{~cm}^{-1}$ (in the range of $2000-2100 \mathrm{~cm}^{-1}$ ) which corresponded to the possible presence of diazo compounds (CNN), such as diazoalkanes, diazo ketones, and diazo esters and СНзO substituted diphenyldiazomethanes to the stretching vibration of the group [38-39]. Therefore, $\mathrm{CH} 3 \mathrm{O}$ substituted diphenyldiazomethanes either in additivity, synergism or counter interaction with other phytochemicals in ethyl acetate fraction may be responsible for the conferment of excellent anti-inflammatory effect observed against bovine erythrocyte lyses. 


\section{Conclusion}

In conclusion, the study demonstrated that the $M$. excelsa leaf extract possessed bioactive functional groups with excellent membrane stabilizing property and anti-inflammatory effects, thus justifying some of their ethnomedicinal uses. However, further chromatographic isolation and characterization of the chemical constituent(s) of the leaf extract, and especially the ethyl acetate fraction with the highest membrane stabilizing property and the in vivo studies will be carried out in future study.

\section{Compliance with ethical standards}

\section{Acknowledgments}

The authors are grateful to Professor E. M Obuotor of the Department of Biochemistry, Faculty of Sciences, Obafemi Awolowo University, Ile-Ife, Osun State for using his laboratory for the anti-inflammatory assay reported in this study.

\section{Disclosure of conflict of interest}

Authors declared no competing interests.

\section{References}

[1] Chandra S, Dey P and Bhattacharya S. (2012). Preliminary in vitro assessment of anti-inflammatory property of Mikania scandens flower extract. Journal of Advanced Pharmaceutical Education Research, 2, 25-31.

[2] Jaya P and Rashmi G. (2011). Evaluation of anti-inflammatory activity of petroleum ether and methanolic extract of Phyllanthus reticulatus leaves. Journal of Advanced Pharmaceutical Education Research, 1, 266-270.

[3] Sosa S, Balicet MJ, Arvigo R, Esposito RG, Pizza C, Altinier G and Tubaro A. (2002). Screening of the topical antiinflammatory activity of some Central American plants. Journal of Ethanopharmacology, 81, 211-215.

[4] Tripathi KD. (2008). Essentials of medical pharmacology. $6^{\text {th }}$ ed. Jaypee Brothers Medical Publishers (P) Ltd.: New Delhi.

[5] Bennett PN and Brown MJ. (2005). Clinical pharmacology. Churchill Livingstone: New Delhi.

[6] Gururaja K and David M. (2016). Spectroscopic signature, antibacterial and anticancer properties of Calotropis gigantea (Linn.) flower. International Journal of Pharmaceutical Science and Research, 7, 1686-1693.

[7] Ashokkumar R and Ramaswamy M. (2014). Phytochemical screening by FT-IR spectroscopic analysis of leaf extracts of selected Indian Medicinal plants. International Journal of Current Microbiology and Applied Sciences, 3, 395-406.

[8] Saxena M and Saxena, J. (2012). Evaluation of phytoconstituents of Acorus calamus by FT-IR and UV-VIS spectroscopic analysis. International Journal of Biological and Pharmaceutical Research, 3, 498-501.

[9] Agyeman VK, Ofori DA, Cobbinah JR and Wagner MR. (2009). Influence of Phytolyma lata (Homoptera psyllidae) on seed growth of Milicia excelsa. Ghana Journal of Forestry, 25, 29-39.

[10] Titanji VPK, Zofou D and Ngemenya MN. (2008). The antimalarial potential of medicinal plants used for the treatment of malaria in Cameroonian folk medicine. Africa Journal of Traditional, Complementary and Alternative Medicine, 5, $302-321$.

[11] Ibrahim JA, Muazzam I, Jegede IA, Kunle OF and Okogun JI. (2007). Ethno-medicinal plants and methods used by Gwandara tribe of Sabo Wuse in Niger State, Nigeria, to treat mental illness. Africa Journal of Traditional, Complementary and Alternative Medicine, 4, 211 - 218.

[12] Ofori DA. (2007). Milicia excelsa (Welw.) C. C. Berg. In: Louppe, D., Oteng-Amoako AA, and Brink M. (Editors). Prota, 7(1): Timbers/Bois d'oeuvre 1. [CD-Rom]. PROTA, Wageningen, Netherlands.

[13] Sonibare MA, Soladoye MO and Subuloye TO. (2008). Ethnobotanical survey of anti-psychotic plants in Lagos and Ogun States of Nigeria. European Journal of Scientific Research, 19, 634 - 644.

[14] Betti JL, Yongo OD, Mbomio DO, Iponga DM and Ngoye A. (2013). An ethnobotanical and floristical study of medicinal plants among the Baka Pygmies in the Periphery of the Ipassa- Biosphere Reserve, Gabon. European Journal of Medicinal Plants, 3, 174 - 205. 
[15] Ndah NJ, Egbe AE, Bechem E, Asaha S, Yengo T, Chia EL and Eyenieh NM. (2013). Ethnobotanical study of commonly used medicinal plants of the Takamanda Rainforest South West, Cameroon. Africa Journal of Plant Science, 7, 21-34.

[16] Padayachee T and Odhav B. (2013). Antimicrobial activity of plant phenols from Chlorophora excelsa and Virgilia oroboides. Africa Journal of Biotechnology, 12, 2254-2261.

[17] Padayachee T and Odhav B. (2001). Anti-amoebic activity of plant compounds from Virgilia oroboides and Chlorophora excelsa. Journal of Ethnopharmacology, 78, 59-66.

[18] Udegbunam, So, Nnaji TO, Udegbunam RI, Okafor JC and Agbo I. (2013). Evaluation of herbal ointment formulation of Milicia excelsa (Welw) C.C Berg for wound healing. Africa Journal of Biotechnology, 12, 3351-3359.

[19] Olajide OA, Kolawole OT, Fagbohun TR and Ajayi FF. (2005). Evaluation of the Anti-inflammatory Properties of Chlorophora excelsa Stem Bark Extract. Journal of Pharmaceutical Biology, 43, 746-748.

[20] Akinpelu LA, Akanmu MA and Obuotor EO. (2018). Mechanism of Anticonvulsant Effects of Ethanol Leaf Extract and Fractions of Milicia excelsa (Moraceae) in Mice. Journal of Pharmaceutical Research International, 23(4), 111.

[21] Sadique J, Al-Rqobah NA, Bughaith MF and El-Gindy AR. (1989). The bioactivity of certain medicinal plants on the stabilization of RBC membrane system. Fitoterapia, 60, 525-532.

[22] Oyedapo 00, Akinpelu BA and Orefuwa SO. (2004). Anti-inflammatory effect of Theobroma cacao, root extract. Journal of Tropical Medicinal Plants, 5, 161-166.

[23] Oyedapo 00, Akinpelu BA, Akinwunmi KF, Adeyinka MO and Sipeolu FO. (2010). Red blood cell membrane stabilizing potentials of extracts of Lantana camara and its fractions. International Journal of Plant Physiology and Biochemistry, 2, 46-51.

[24] Balunas MJ and Kinghorn AD. (2005). Drug discovery from medicinal plants. Life Science, 78, 431-441.

[25] Ganie SA and Yadav SS. (2015). FT-IR Spectroscopic Analysis of Holoptelea integrifolia (Roxb.) Planch Seed Extracts and their Antibacterial Activity. Research Journal of Medicinal Plants, 9, 417-426.

[26] Negi JS, Singh P and Rawat B. (2011). Chemical constituents and biological importance of swertia: A review. Current Research in Chemistry, 3, 1-15.

[27] Chuang WC, Young DS, Liu LK and Sheu SJ. (1996). Liquid chromatographic-electrospray mass spectrometric analysis of Coptidis Rhizoma. Journal of Chromatography, 755, 19-26.

[28] Idowu TO, Ogundaini AO, Adesanya SA, Onawunmi GO, Osungunna MO, Obuotor EM and Abegaz BM. (2016). Isolation and characterization of chemical constituents from Chrysophyllum albidum G. Don-Holl stem-bark extracts and their antioxidant and antibacterial properties. Africa Journal of Traditional, Complementary and Alternative Medicine, 13(5), 182-189.

[29] Aiello A, Fattorusso E, Imperatore C, Irace C, Luciano P, Menna M, Santamaria R and Vitalone R. (2011). Zorrimidazolone, a bioactive alkaloid from the non-indigenous Mediterranean stolidobranch Polyandrocarpa zorritensis. Marine Drugs, 9, 1157-1165.

[30] Shang JH, Cai XH, Feng T, Zhao YL, Wang JK, Zhang LY, Yan M and Luo XD. (2010). Pharmacological evaluation of Alstonia scholaris: Anti-inflammatory and analgesic effects. Journal of Ethnopharmacology, 129, 174-181.

[31] Idowu TO, Ogundaini AO, Salau A0, Obuotor EM, Bezabih M and Abegaz BM. (2010). Doubly linked, A-type proanthocyanidin trimer and other constituents of Ixora coccinea leaves and their antioxidant and antibacterial properties. Phytochemistry, 71, 2092-2098.

[32] Ezell SJ, Li H, Xu H, Zhang X, Gurpinar E, Zhang X, Velu XE, Wang W and Zhang R. (2010). Preclinical pharmacology of BA-TPQ, a novel synthetic iminoquinone anticancer agent. Marine Drugs, 8, 2129-2141.

[33] Idowu TO, Iwalewa EO, Aderogba MA, Akinpelu BA and Ogundaini A0. (2006). Antinociceptive, antiinflammatory and antioxidant activities of eleagnine: An alkaloid isolated from Chrysophyllum albidum seed cotyledons. Journal of Biological Sciences, 6, 1029-1034.

[34] Arts IC and Hollmn PC. (2005). Polyhenols are disease risk in epidemiological studies. The American Journal of Clinical Nutrition, 81, 317-325.

[35] Scalbert A, Manach C, Morand C, Remesy C and Jimenez L. (2005). Dietary polyhenols and the prevention of disease. Critical Review in Food Science and Nutrition, 45(4), 287-306. 
[36] Henriques AT, Limberger RP, Kerber VA and Moreno PRH. (2004). Alcalóides: Generalidades e Aspectos Básicos. In Farmacognosia: Da Planta Ao Medicamento, $5^{\text {th }}$ ed.; Simões CMO, Schenkel EP, Gosmann G, Mello JCP, Mentz LA, Petrovick PR, Eds.; Editoras of the Universidades Federais de Santa Catarina and Rio Grande do Sul: Porto Alegre/Florianópolis, Brazil, Chapter 29, 765-792.

[37] Binggi L, Changgi $Z$ and Yurui L. (1983). Studies on the contents of glycosaminoglycans from lungs of silicotics rats and tetrandrine treated silicotic rats. Ecotoxicology and Environmental Safety, 7, 323-329.

[38] Stánkovský Š and Kováč Š. (1974). Infrared spectra of heterocumulenes. Ш. Vibrational wavenumbers and integrated absorption intensities of the diazo group of some diphenyldiazomethanes. Chemicke Zvesti, 28, 238 242.

[39] Yates P, Shapiro BL, Yoda N and Fugger J. (1957). Aliphatic Diazo Compounds. III. Infrared Spectra. Journal of American Chemical Society, 79, 5756-5760.

\section{How to cite this article}

Akinpelu LA, Olawuni IJ, Ogundepo GE, Adegoke AM, Olayiwola G and Idowu TO. (2019). Spectroscopic analysis and anti-inflammatory effects of Milicia excelsa (Moraceae) leaf and fractions. GSC Biological and Pharmaceutical Sciences, 6(3), 51-60. 